\title{
GENDER EQUAL ACCESS TO GOODS AND SERVICES
}

\section{DZIMUMLĪDZTIESİGA PIEKL̨UVE PRECĒM UN PAKALPOJUMIEM}

\author{
Kristīne Dupate, Dr. iur. \\ Latvijas Universitātes Juridiskās fakultātes \\ Starptautisko un Eiropas tiesību zinātṇu katedras asociētā profesore
}

\begin{abstract}
Anotācija
Direktīva 2004/113/EK, kura prasa nodrošināt sievietēm un vīriešiem vienlīdzīgu piekḷuvi precēm un pakalpojumiem, tika pien̦emta 2004. gadā. Tā bija jāievieš lìdz 2007. gada 21. decembrim. Neskatoties uz to, ka ir pagājuši jau 13 gadi, kopš dzimumvienlīdzīgai piekḷuvei precēm un pakalpojumiem bija jādarbojas praksē, līdztiesība šajā jomā gana bieži netiek nodrošināta. Tas skaidrojams ar to, ka līdz šim nav bijis izvērstākas diskusijas par līdztiesību šajā jomā ne no atbildīgo institūciju puses, nedz arī plašākā sabiedrībā, līdz ar to ievērojama dạa preču pārdevēju un pakalpojumu sniedzēju par šo tiesisko regulējumu neko nezina. Lai pievērtu uzmanību jautājumam par dzimumlīdztiesīgu piekḷuvi precēm un pakalpojumiem un šo tiesību nodrošināšanu praksē, šajā rakstā autore pievēršas, pirmkārt, Direktīvas 2004/113/EK materiālā un personālā tvēruma un galveno jēdzienu skaidrošanai, otrkārt, problēmām, kuras saistītas ar šo tiesību nodrošināšanu praksē, un, treškārt, analizē šîs direktīvas normu ieviešanu Latvijas tiesiskajā regulējumā. Autore secina, ka Direktīva 2004/113/EK Latvijā nav ieviesta pilnīgi, jo tiesiskais regulējums neietver tās privātās personas, kuras piedāvā preces un pakalpojumus ārpus savas profesionālās darbības jomas. Turklāt apdrošināšanas jomā nav skaidrs, vai visās apdrošināšanas polisēs būtu obligāti iekḷaujami riski, kuri saistīti ar grūtniecību un maternitāti. Ir apšaubāmi, vai, nenodrošinot nevienu šo tiesību ievērošanas administratīvās kontroles mehānismu, tiek ievērots ES tiesību aizsardzības līdzekḷu efektivitātes princips.
\end{abstract}

Atslēgvārdi: dzimumu līdztiesība, diskriminācijas aizliegums, Direktīva 2004/113/ EK, piekḷuve precēm un pakalpojumiem, ievērošana praksē, ieviešana Latvijas tiesību aktos.

Keywords: gender equality, prohibition of discrimination, Directive 2004/113/EC, access to and supply of goods and services, enforcement in practice, implementation in Latvian normative acts. 


\section{Introduction}

Directive 2004/113/EC ${ }^{1}$ requiring equal access to goods and services for men and women was adopted on 2004. It had to be transposed by 21 December 2007. Although already 13 years have passed since equal treatment obligation in the field of access to and supply of goods and services is in force, this aspect of equality rights is rarely discussed and brought to attention of the law enforcement bodies and wider public, thus, due to lack of awareness, it is not surprising that discriminatory practices are still present in our everyday lives.

The aim of this article is, firstly, to explain the substance of the rights provided by Directive 2004/113/EC, including material and personal scope and the concepts, secondly, to consider the issues related to practical application and, thirdly, to assess the implementation in Latvia.

\section{The scope of Directive 2004/113/EC}

The material scope of Directive 2004/113/EC encompasses the following aspects.

Firstly, the concepts "goods" and "services" have to be interpreted according to the definitions related to free movement of goods and services as defined by the Treaty on the Functioning of the European Union (further - the TFEU). ${ }^{2}$ According to Article 28(2) of the TFEU, "goods" are all "products originating in Member States and to products coming from third countries which are in free circulation in Member States", while Article 57 of the TFEU provides "“services" "within the meaning of the Treaties where they are normally provided for remuneration."3

European Commission considers that Directive 2004/113/EC also covers services remunerated by third parties, ${ }^{4}$ thus it also includes public health services. ${ }^{5}$

Secondly, Directive 2004/113/EC applies to all persons - public and private, ${ }^{6}$ which supply goods and services available in public, i.e., those offered to the abstract cycle of persons. ${ }^{7}$ It means that directive is applicable to all goods and services offered in the public space (website, advertisement), irrespective of whether a person offering it acts within his/her professional capacity or outside it. At the same time, services offered within the area of private and family life, even if it is done publicly (by advertisement) fall outside the scope of the directive (for

1 Council Directive 2004/113/EC of 13 December 2004 implementing the principle of equal treatment between men and women in the access to and supply of goods and services, OJ L 373, 21.12.2004, pp. 37-43.

2 Consolidated version of the Treaty on the Functioning of the European Union, OJ C 326, 26.10.2012, pp. 47-390.

3 See Point 11 of the Preamble of the Directive 2004/113/EC.

${ }^{4}$ Report from the Commission of the European Union to the European Parliament, the Council and the European Economic and Social Committee, Report on the application of Council Directive 2004/113/ EC implementing the principle of equal treatment between men and women in the access to and supply of goods and services, COM/2015/0190 final.

5 Directive 2004/113/EC does not cover issues related to social security as covered by Directive Council Directive 79/7/EEC of 19 December 1978 on the progressive implementation of the principle of equal treatment for men and women in matters of social security, OJ L 6, 10.1.1979, pp. 24-25.

6 Article 10 of Directive 2004/113/EC.

7 Article 3(1) of Directive 2004/113/EC. 
example, renting out a room in private apartment, wherein the proprietor resides him/herself). ${ }^{8}$

Directive 2004/113/EC does "not apply to the content of media and advertising nor to education." 9

Further Directive 2004/113/EC, beyond protecting women and men, also applies to discrimination arising from the gender reassignment, as it follows form the case-law of the Court of Justice of the EU (further - the CJEU). ${ }^{10}$

Directive 2004/113/EC in its substance restricts one of the fundamental principles of the contract law - freedom to choose contractual partner. Directive 2004/113/EC defines it, as follows:

This Directive does not prejudice the individual's freedom to choose a contractual partner as long as an individual's choice of contractual partner is not based on that person's sex. ${ }^{11}$

\section{Protection against discrimination}

Directive 2004/113/EC prohibits the following types of discrimination direct, indirect, direct, indirect discrimination, harassment, sexual harassment, instruction to discriminate, victimization. Similarly to other gender equality directives $^{12}$ and the case-law of the CJEU, ${ }^{13}$ direct discrimination occurs where a person is treated less favourably due to pregnancy and maternity.

As the regards the content of the principle of discrimination itself, the CJEU has repeated its well-established case-law, namely, that:

[..] the principle of equal treatment requires that comparable situations must not be treated differently, and different situations must not be treated in the same way, unless such treatment is objectively justified [...].14

It means that principle of non-discrimination is not limited to the cases where persons are in equal or same situations but requires provision of different rights to the persons in different situations, taking into account respective difference. Latter obligation is envisaged in order to provide equal opportunities for both sexes taking into account different social situations persons may find themselves in because of different social gender roles (gender stereotypes), and also due to biological differences between sexes. An example depicting barriers

\footnotetext{
${ }^{8}$ Report from the Commission of the European Union to the European Parliament, the Council and the European Economic and Social Committee, Report on the application of Council Directive 2004/113/ EC implementing the principle of equal treatment between men and women in the access to and supply of goods and services, COM/2015/0190 final; 1 .

9 Article 3(3) of Directive 2004/113/EC.

10 The CJEU decision in case C-13/94 P v. S and Cornwall County Council, ECLI:EU:C:1996:170 and C-423/04 Sarah Margaret Richards v. Secretary of State for Work and Pensions, ECLI:EU:C:2006:256.

11 Article 3(2) of Directive 2004/113/EC.

12 See Directive 2006/54/EC of the European Parliament and of the Council of 5 July 2006 on the implementation of the principle of equal opportunities and equal treatment of men and women in matters of employment and occupation (recast), OJ L 204, 26.7.2006, pp. 23-36.

13 See, for example, the decision of the CJEU in case C-177/88 Elisabeth Johanna Pacifica Dekker v. Stichting Vormingscentrum voor Jong Volwassenen (VJV-Centrum) Plus, ECLI:EU:C:1990:383.

14 The CJEU decision in case C-236/09 Association belge des Consommateurs TestAchats ASBL, etc. v. Conseil des Ministres, ECLI:EU:C:2011:100, para. 28.
} 
women face more frequently than men due to different social gender roles is child-care obligation, which is mostly taken up by mothers. Consequently, they are most frequently the "victims" of environmental barriers such as buildings with stairs and without lift, which makes the access with baby-carriage cumbersome. Another example relates to biological differences - unequal access to sanitary facilities (toilets), if such facilities are provided on shared basis. Planning of the buildings still does not take into account different biological needs and thus different time periods spent in toilets by men and women. As a consequence, females spend far more time queuing in all public spaces.

At the same time, Directive 2004/113/EC does not require absolutely equal treatment. Article 4(5) allows exception, in particular:

This Directive shall not preclude differences in treatment, if the provision of the goods and services exclusively or primarily to members of one sex is justified by a legitimate aim and the means of achieving that aim are appropriate and necessary.

As explained by Point 16 of the Preamble of Directive 2004/113/EC,

A legitimate aim may, for example, be the protection of victims of sex-related violence (in cases such as the establishment of single-sex shelters), reasons of privacy and decency (in cases such as the provision of accommodation by a person in a part of that person's home), the promotion of gender equality or of the interests of men or women (for example single-sex voluntary bodies), the freedom of association (in cases of membership of single-sex private clubs), and the organisation of sporting activities (for example single-sex sports events).

\section{Equal treatment in the field of insurance and financial services}

Directive 2004/113/EC specifically regulates equal treatment with regard to insurance and financial services. It is because in such sectors actuarial factors are used in calculation of premiums and benefits. The problem with actuarial factors lies in the fact that they take into account risks and statistical data based on gender. In order to tackle such unequal treatment in insurance and financial services, Article 5(1) provides that

use of sex as a factor in the calculation of premiums and benefits for the purposes of insurance and related financial services shall not result in differences in individuals' premiums and benefits.

As explained by the Commission in its 2012 Guidelines, the use of actuarial factors is not entirely prohibited. It is prohibited only at the individual level, while

use [of actuarial factors] is allowed in the calculation of premiums and benefits at the aggregate level, as long as it does not lead to differentiation at individual level. ${ }^{15}$

${ }^{15}$ Guidelines on the application of Council Directive 2004/113/EC to insurance, in the light of the judgment of the Court of Justice of the European Union in case C-236/09 (Test-Achats), para.14. Available at: https:// eur-lex.europa.eu/legal-content/EN/TXT/HTML/?uri=CELEX:52012XC0113(01)\&from=en [last viewed 27.04.2021]. 
Such explanation was given by the European Commission following the CJEU judgement in case Test-Achat. ${ }^{16}$ It is the only decision so far adopted by the CJEU relating to Directive 2004/113/EC. In Test-Achat case, the CJEU declared exemption allowing use of actuarial factors at the individual level as provided by Article 5(2) of Directive 2004/113/EC void as from 21 December 2012. The CJEU based such decision on the consideration that Article 5(2) does not set any temporary limit on respective exemption and such situation is contrary to the principle of equal treatment between men and women as enshrined in Articles 21 and 23 of the CFREU. ${ }^{17}$

\section{Application of non-discrimination in access to and supply of goods and services in practice}

There is no single decision delivered by the CJEU as to how Directive 2004/113/EC must be interpreted (except the decision in Test-Achat case). More detailed interpretation would be especially needed with regard to the application of the exemption provided by Article 4(5) of Directive 2004/113/EC allowing differences in treatment in "the provision of the goods and services exclusively or primarily to members" under condition that there is a legitimate aim, and the means used for achievement of that aim are proportionate.

Numerous practices of differential treatment have been detected around the EU Member States. In most cases, these practices related to different pricing of services and refusal to provide services. Regarding different pricing, it is most widespread in hairdressing services, where different prices are set for female and male haircuts, night clubs also frequently offer free entrance to women. ${ }^{18}$ As regards refusal to provide the service, the practices mentioned as examples included asking breastfeeding mothers leaving restaurants, ${ }^{19}$ denying access to the shops with baby carriage, ${ }^{20}$ ban on women entering barbershops. ${ }^{21}$ According to the scholars, respective practices must be considered as discriminatory.

More problematic from the perspective of legal qualification are sex-segregated services, such as separate sport clubs, separate training classes, while separate facilities for men and women in saunas, spas and swimming pools are seen as justifiable on the grounds of privacy decency, safety, etc. ${ }^{22}$

16 The CJEU decision in case C-236/09 Association Belge des Consommateurs TestAchats ASBL, et al. v. Conseil des Ministres, ECLI:EU:C:2011:100.

17 Charter of Fundamental Rights of the European Union, OJ C 326, 26.10.2012, pp. 391-407.

18 Susanne Burri, Aileen McColgan, European Network of legal experts in the field of gender equality, Sex-segregated Services, European Commission, 2008. Available at: https://www.equalitylaw.eu/ downloads/4555-sex-segregated-services-pdf-1-134-kb [last viewed 27.04.2021].

19 Sarah Bourke, Equal Treatment between men and women in the access to and supply of goods and services, presentation at European Law Academy on 2015. Available at: http://www.era-comm.eu/oldoku/ SNLLaw/08_Access_to_goods_and_services/2015_03_Bourke_EN.pdf [last viewed 27.04.2021].

20 The investigation case by the Ombudsperson of the Republic of Latvia, information provided on February 2021.

${ }^{21}$ Maria Y. Lee, Sex-segregated services - their place in EU anti-discrimination law and their relationship to positive action measures, E. L. Rev., 2019, 44(5).

22 Susanne Burri, Aileen McColgan, European Network of legal experts in the field of gender equality, Sex-segregated Services, European Commission, 2008. Available at: https://www.equalitylaw.eu/ downloads/4555-sex-segregated-services-pdf-1-134-kb [last viewed 27.04.2021]; Maria Y. Lee, Sexsegregated services - their place in EU anti-discrimination law and their relationship to positive action measures, E. L. Rev., 2019, 44(5). 
The scholars in their writings have arrived at the conclusion that ban on access or restricted access to goods and services to either sex may be justified only by consideration of protecting other fundamental rights and freedoms, for example, for male private clubs - freedom of association, for sex-segregated facilities - protection of privacy and decency. Such finding is supported by the point 3 of Preamble of Directive 2004/113/EC, stating that:

While prohibiting discrimination, it is important to respect other fundamental rights and freedoms, including the protection of private and family life and transactions carried out in that context and the freedom of religion.

On the other hand, it is unlikely that purely commercial interest would be accepted as a legitimate aim for the ban on access to service, like ban on women to enter barbershop due to desire of the service providers to ensure "'masculine" space, because such consideration is not driven by the right to freedom of association but rather by the interest in commercial gain. ${ }^{23}$

However, the respective assessment of state of affairs with regard to the permissible justification of different treatment with regard to access to goods and services, i.e., interpretation of Article 4(5) of Directive 2004/113/EC, is changing, as most of presently permissible differences in treatment are based on gender roles and societal attitudes. As pointed out by Maria Y. Lee, socially and historically defined concepts such as sex/gender and related issue of nudity, decency, privacy and sexuality are not static and unalterable. They are constantly changing. It means that in the future sex-segregated services may become unnecessary. ${ }^{24}$

\section{Implementation in Latvia}

Directive 2004/113/EC in Latvia is implemented by two legal acts. It is the Law on the Protection of Consumer Rights ${ }^{25}$ and the Law on Insurance and Reinsurance. ${ }^{26}$

The Law on the Protection of Consumer Rights was used for the implementation of the principle of equal treatment between men and women with regarding access to and supply of goods and services in general. Article $3^{1}$ of the Law on the Protection of Consumer Rights provides prohibition of discrimination, lists types of discrimination (direct, indirect, harassment, sexual harassment and instruction to discriminate) and definitions of direct, indirect discrimination, as well as harassment and sexual harassment.

The Law on Insurance and Reinsurance implements requirements of Article 5 of Directive 2004/113/EC, in particular, Article 9 of the Law on Insurance and Reinsurance prohibits the use of sex as a factor in insurance. It also prohibits the definition of different premiums and benefits by reason of pregnancy and maternity.

\footnotetext{
${ }^{23}$ Maria Y. Lee, Sex-segregated services - their place in EU anti-discrimination law and their relationship to positive action measures, E. L. Rev., 2019, 44(5).

24 Ibid.

25 Patērētāju tiesību aizsardzības likums, Official Gazette, No. 104/105, 1 April 1999.

${ }^{26}$ Apdrošināšanas un pārapdrošināšanas likums, Official Gazette, No. 124, 30 June 2015.
} 
However, the implementation measures undertaken by Latvian legislator does not ensure complete implementation of the requirements under Directive 2004/113/EC.

First of all, not all goods and services available publicly are covered by nondiscrimination rights. Latvian law does not cover goods and services which are publicly offered by natural persons outside commercial activities - for example, if a natural person publicly advertises the sale of his/her own apartment. It is so, because the Law on Protection of Consumer Rights applies to transactions provided within the scope of commercial activities only. ${ }^{27}$ The Civil Law, ${ }^{28}$ which provides the basic regulation covering contract law, does not contain any provisions on the principle of non-discrimination.

Secondly, there is a problem with pregnancy- and maternity-based discrimination in insurance sector. The implementing provisions (Article 9 of the Law on Insurance and Reinsurance) only require the definition of equal premiums and benefits irrespectively of sex, pregnancy and maternity. Like Article 5 of Directive 2004/113/EC, the respective provisions do not require the insurance programmes to include the risks related to the pregnancy and maternity. As a result, no insurance company in Latvia provides any standard travel and health insurance programme covering risks related to pregnancy and maternity. Consequently, the norms prohibiting pregnancy and maternity discrimination turn out to be meaningless in practice. No legal act stipulates what kinds of risks have to be covered by private insurance programmes, thus, insurance companies simply do not include risks relating to pregnancy or maternity. There is no case law on this.

However, the most important shortcoming in the implementation of Directive 2004/113/EC in Latvia in the view of the present author relates to enforcement measures and remedies available for the protection of the rights therein. The EU law requires that the remedies available under national law for the enforcement and protection of the rights provided by the EU comply with the principle of effectiveness. The respective principle implies that national remedies "must not render practically impossible or excessively difficult the exercise of rights conferred by EU law" ${ }^{29}$ In practice, it means that, in order to comply with the principle of effectiveness, a Member State must stipulate civil and administrative, and sometimes even criminal liability and sanctions for breach of the rights provided by the EU law. It is not the case with regard to the remedies available in case of discrimination concerning access to and provision of goods and services in Latvia. The only option for a victim is to take the case to court. However, access to the courts is limited due to high litigation costs (in comparison to the average income of people in Latvia) and the difficulty in collecting evidence. There is no administrative liability for breaching the principle of equal treatment with regard to access to and provision of goods and services in Latvia and no responsible administrative institution in charge of supervising the compliance with Directive 2004/113/EC. It allows drawing the conclusion that in practice Latvian law does not ensure effective protection of the rights under Directive 2004/113/EC.

\footnotetext{
27 Law on Protection of Consumer Rights, Article 1(4).

${ }^{28}$ Civillikums. Ceturtā daḷa. Saistību tiesības, 28 January 1937.

29 The CJEU decision in case C-177/10, Francisco Javier Rosado Santana v. Consejería de Justicia y Administración Pública de la Junta de Andalucía, ECLI:EU:C:2011:557, para. 89.
} 


\section{Conclusions}

The principle of non-discrimination is not limited to cases where persons are in equal or same situations but require provision of different rights to the persons in different situations, taking into account the respective difference. The latter obligation is envisaged for providing equal opportunities for both sexes taking into account different social situations persons may find themselves in because of different social gender roles (gender stereotypes), and also due to biological differences between sexes.

Although it is already 13 years since equal treatment obligation in the field of access to and supply of goods and services is in force, this aspect of equality rights is rarely discussed and brought to attention to the law enforcement bodies and wider public in Latvia. It is also subject to diverse national case-law in the EU Member States, as the CJEU case-law shedding the light on permissible differences in treatment between men and women in this field is almost absent.

The most problematic issue from the perspective of legal qualification relates to sex-segregated services. The scholars have agreed that ban on access or restricted access to goods and services to either sex may be justified only by consideration of protecting other fundamental rights and freedoms. It is unlikely that purely commercial interest would be accepted as a legitimate aim for the ban on access to service.$^{30}$ However, as social roles are constantly changing, it is clear that standards or necessity for gender-specific or segregated services will change.

The implementation of Directive 2004/113/EC in Latvia is incomplete. Latvian law does not cover goods and services which are publicly offered by natural persons outside their commercial activities. Due to unclear legal regulation under Article 5 of Directive 2004/113/EC itself, no insurance company in Latvia provides any standard travel and health insurance programme covering risks related to pregnancy and maternity. Consequently, the norms prohibiting pregnancy and maternity discrimination turn out to be meaningless in practice.

The only option for a victim of discrimination in Latvia is to bring the case before court. However, access to the courts is limited due to high litigation costs (in comparison to the average income of people in Latvia) and the difficulty in collecting evidence. There is no administrative liability for breaching the principle of equal treatment regarding access to and provision of goods and services. Therefore, in practice Latvian law does not ensure effective protection of the rights under Directive 2004/113/EC.

${ }^{30}$ Maria Y. Lee, Sex-segregated services - their place in EU anti-discrimination law and their relationship to positive action measures, E. L. Rev., 2019, 44(5). 